\title{
MLL/MLLT1 Fusion Gene
}

National Cancer Institute

\section{Source}

National Cancer Institute. MLL/MLLT1 Fusion Gene. NCI Thesaurus. Code C99321.

A fusion gene that results from a chromosomal translocation $\mathrm{t}(11 ; 19)(\mathrm{q} 23 ; \mathrm{p} 13.3)$ which fuses the $5^{\prime}$ half of the MLL gene to most of the MLLT1 gene. This rearrangement is associated with acute lymphocytic leukemia and other leukemia types. 